\title{
Maxillary Rhinosinusitis Profil In General Hospital Of Haji Surabaya On January-December 2017
}

\author{
Indra Setiawan \\ Faculty of Medicine, University of Muhammadiyah Malang \\ j1. Bendungan Sutami 188a Malang, East Java, Indonesia \\ Email :indra@umm.ac.id \\ Received : Mart 18 ${ }^{\text {th }} 2021$. Revised : Apr 10 $0^{\text {th }}$ 2021. Published : June $10^{\text {th }} 2021$ \\ DOI : https://doi.org/10.22219/sm.Vol17.SMUMM1.16009
}

\begin{abstract}
Chronic rhinosinusitis in various countries in the world and Indonesia shows an increase from time to time. At General Hospital of Haji Surabaya, the prevalence of chronic rhinosinusitis has increased from $10.13 \%$ in 2016 to $10.26 \%$ in 2017. Various factors are thought to cause chronic rhinosinusitis. Chronic rhinosinusitis can interfere with the quality of life and lead to serious complications if left untreated. To determine the profile of chronic rhinosinusitis in General Hospital of Haji Surabaya for January-December 2017 Period. Analytic observational with cross-sectional study approach. Used the total sampling method. Based on patients diagnosed with chronic rhinosinusitis with complete medical record data. The sample in this study were 132 patients. Most chronic rhinosinusitis patients were aged 36-45 years as many as 26 patients (19.69\%) and the least number of patients was more than 65 years old as many as 6 patients, women $(67.40 \%)$ and 43 patients in men $(32,60 \%)$. Symptoms of nasal congestion in 79 patients $(59.84 \%)$, cough as many as 25 patients $(18.93 \%)$, septal deviation as many as 51 patients $(38.63 \%)$ and at least 4 patients $(3.03 \%)$ of nasal polyps. Most rhinosinusitis patients in this study were aged 36-45 years, women with symptoms of nasal congestion and septal deviation as the most comorbidities.
\end{abstract}

Keywords : Chronic rhinosinusitis, congestion, symptoms.

Copyright (C) 2021, Indra S This is an open access article under the CC-BY-SA license

\section{INTRODUCTION}

Chronic rhinosinusitis can cause serious quality of life and complications if not treated properly. Rhinosinusitis is inflammation of the nose and paranasal sinuses characterized by the presence of two or more symptoms, such as nasal congestion, nasal obstruction/congestion, runny nose (anterior/posterior nasal discharge), facial pain or pressure in the face, decreased or eliminated nasal discharge. Anatomically, rhinosinusitis is divided into 4 types, including maxillar rhinosinusitis, ethmoidal rhinosinusitis, frontal rhinosinusitis, and sphenoidal rhinosinusitis. Maxillar rhinosinus is most often found because the inflamed one is the largest sinus compared to the other sinuses and is also located above or near the root of the molars.

To determine the incidence and profile of chronic rhinosinusitis at the General Hospital of Haji Surabaya for the period of January - December 2017. 


\section{METHODS}

Analytic observational with cross-sectional study approach. The study population was all rhinosinusitis patients attending the ENT Clinic RSU Haji Surabaya for the period of JanuaryDecember 2017.

\section{RESULT AND DISCUSSION}

This study was conducted on 132 patients diagnosed with chronic rhinosinusitis at the ENT Clinic of General Hospital of Haji Surabaya.

Tabel 1. Distribution of Chronic Rhinosinusitis by Age

\begin{tabular}{ccc}
\hline \multirow{2}{*}{ Age (years) } & \multicolumn{2}{c}{ Chronic Rhinosinusitis } \\
\cline { 2 - 3 } & Frequency & Percentage \\
\hline$<15$ & 16 & $12,12 \%$ \\
\hline $16-25$ & 24 & $18,20 \%$ \\
\hline $26-35$ & 19 & $14,39 \%$ \\
\hline $36-45$ & 26 & $19,69 \%$ \\
\hline $46-55$ & 22 & $16,66 \%$ \\
\hline $56-65$ & 19 & $14,40 \%$ \\
\hline$>65$ & 6 & $4,54 \%$ \\
\hline Total & 132 & $100 \%$ \\
\hline
\end{tabular}

From the data shown in the table above, it was found that the most chronic rhinosinusitis patients were at the age of 36-45 years as many as 26 patients $(19.69 \%)$ and the least number were at the age of more than 65 years as many as 6 patients $(4.54 \%)$.

Tabel 2. Distribution of Chronic Rhinosinusitis by Gender

\begin{tabular}{ccc}
\hline \multirow{2}{*}{ Gender } & \multicolumn{2}{c}{ Chronic Rhinosinusitis } \\
\cline { 2 - 3 } & Frequency & Percentage \\
\hline Laki-Laki & 43 & $32,60 \%$ \\
\hline Perempuan & 89 & $67,40 \%$ \\
\hline Jumlah & 132 & $100 \%$ \\
\hline
\end{tabular}

The results obtained in the table above, the number of chronic rhinosinusitis patients in women is more than in men, namely as many as 89 patients (67.40\%) and in men 43 patients $(32.60 \%)$. 
Tabe1 3. Distribution of Chronic Maxillaris Sinusitis Based on Clinical Symptoms

\begin{tabular}{cccc}
\hline \multirow{2}{*}{ Clinical symptoms } & \multicolumn{3}{c}{ Chronic Rhinosinusitis } \\
\cline { 2 - 4 } & Yes & No & Total \\
\hline Smelly secretions & $57(43,19 \%)$ & $75(56,81 \%)$ & $132(100 \%)$ \\
\hline Rhinorrhea & $76(57,58 \%)$ & $56(42,42 \%)$ & $132(100 \%)$ \\
\hline Nasal congestion & $79(59,84 \%)$ & $53(40,16 \%)$ & $84(100 \%)$ \\
\hline Facial pain & $44(33,33 \%)$ & $88(66,67 \%)$ & $132(100 \%)$ \\
\hline Headeache & $67(50,76 \%)$ & $65(49,24 \%)$ & $132(100 \%)$ \\
\hline Cough & $25(18,93 \%)$ & $107(81,07 \%)$ & $132(100 \%)$ \\
\hline
\end{tabular}

The results obtained in the table above showed that the most clinical symptoms in chronic rhinosinusitis patients were nasal congestion as many as 79 patients $(59.84 \%)$ and the least was cough as many as 25 patients $(18.93 \%)$.

Tabel 4. Concomitant diagnosis of Chronic Rhinosinusitis

\begin{tabular}{ccc}
\hline \multirow{2}{*}{ Other causes } & \multicolumn{2}{c}{ Chronic Rhinosinusitis } \\
\cline { 2 - 3 } & Frequency & Percentage \\
\hline Septal Deviation & 51 & $38,63 \%$ \\
\hline Nasal Polyps & 4 & $3,03 \%$ \\
\hline Chronic Adenotonsillitis & 5 & $3,70 \%$ \\
\hline Dental caries & 25 & $18.94 \%$ \\
\hline Allergic Rhinitis & 20 & $15,25 \%$ \\
\hline Rhinis Vasomotor & 27 & $20,45 \%$ \\
\hline Total & 132 & $100 \%$
\end{tabular}

(Source: Processed secondary data, 2018)

Based on the data above, it was found that the most comorbid diagnosis of chronic rhinosinusitis was septal deviation as many as 51 patients (38.63\%) and the least was nasal polyp as many as 4 patients $(3.03 \%)$.

The number of samples with a strong suspicion of chronic maxillary sinusitis was 132 patients, which are 84 patients with positive chronic maxillary sinusitis and 48 patients with negative chronic maxillary sinusitis.

The most common age found in chronic maxillary sinusitis patients was the age of 46-55 years as many as 17 patients $(20.2 \%)$. The results obtained are similar to research by Sukahandoko (2017) at ENT Poli RSUD Dr. Soetomo Surabaya stated that the age who suffered the most from chronic rhinosinusitis was the age of 46-55 years as many as 17 patients (27.42\%) (Sukahandoko, 2017). Based on the histopathology of chronic rhinosinusitis, the number of cases in adults 
compared to children is higher, because children have polypoid changes with increased edema in lamina propia, mucosal gland hyperplasia, and defoliation of the nasal epithelium which are thought to occur due to longer inflammation in adulthood. Polypoid changes can cause the sinus ostium to become narrow so that mucus drainage in the sinuses is disturbed and hypoxia occurs because the sinus ostium becomes narrow. In a hypoxic state, the mucus gland is disturbed causing changes in the quality and quantity of mucus where the secret becomes thicker accompanied by changes in $\mathrm{pH}$ so that it becomes a fertile medium for the growth of germs or bacteria. Bacteria will also produce toxins that will damage cilia. Therefore there is inflammation in the sinuses. Under these conditions, the development of bacteria also increases, resulting in chronic rhinosinusitis (Mahdavinia, 2013). Another opinion says that this may be because the adult age group is an active age group and is often exposed to pollutants or irritant substances that may cause or aggravate the occurrence of chronic rhinosinusitis so that more patients in the adult age group go to the hospital. (Gultom, 2014). Research conducted by Mahdavinia (2013) which examined the epithelium and submucosa of chronic rhinosinusitis patients at the age of children had higher lymphocytes, monocytes/macrophages, neutrophils and NK cells, and submucosal glands that had fewer eosinophils infiltration in the mucosa and submucosa when compared to rhinosinusitis. chronic in adulthood. A higher number of monocytes/macrophages, neutrophils, and NK cells in children indicates higher innate immunity than in adults. Children under 18 years of age have strong immunity from inflammatory cell infiltrates (Mahdavinia, 2013). In theory, no one has explained the relationship between age and the occurrence of chronic rhinosinusitis, but the pathophysiology of chronic rhinosinusitis is multifactorial. Therefore, even though the innate immune system is strong if the patient's cold often appears so that it often clogs KOM. Over time it will become acute rhinosinusitis because acute rhinosinusitis eventually inflammation the sinuses which cause narrowing of $\mathrm{KOM}$ and bacteria in the sinuses will further develop. Bacteria will also produce toxins that will damage the cilia so that the mucus in the sinuses cannot come out and chronic rhinosinusitis occurs (Soetjipto and Mangunkusumo, 2012).

The sex most commonly found in patients with chronic maxillary sinusitis was female as many as 63 patients (75\%). Research conducted by Gultom (2014) at ENT Poli RSUD Dr. Pirngadi Medan stated that the sex with the most chronic rhinosinusitis was women as many as 35 patients (71.4\%) (Gultom, 2014). Women are more prone to obstruction and infection because their sinus ostium is smaller than men. Therefore, mucus drainage in the sinuses in women is easily disturbed and hypoxia occurs because the sinus ostium in women is smaller than in men. In a hypoxic state, the mucus gland is disturbed which causes changes in the quality and quantity of mucus where the secret becomes thicker with changes in $\mathrm{pH}$ so that it becomes a fertile medium for the growth of germs or bacteria. Bacteria will also produce toxins that will damage cilia. Accordingly, there is inflammation in the sinuses. Under these conditions, the development of bacteria also increases, resulting in chronic rhinosinusitis (Soetjipto and Mangunkusumo, 2012). Another opinion says that 
women have the hormone estrogen which plays a role in increasing the inflammatory response. In the unstable state of the estrogen hormone, the vascularization of the nasal mucosa can be disturbed, resulting in cell damage, impaired oxygenation and impaired function of the nasal mucosa which damages the respiratory epithelium, resulting in interference with mucociliary clearance in $\mathrm{KOM}$ or sinus. If the mucociliary clearance is disturbed, it is one of the factors for chronic rhinosinusitis (Ference et al., 2015). Kayguzuz et al (2013) who studied at the ENT clinic at the Kayseri Develi Hospital in Turkey stated that the sex that suffered the most from chronic rhinosinusitis was male as many as 74 patients (74.7\%) (Kayguzuz et al., 2013). Based on the theory, it is suspected that male activity -Males are more often outside the house so they are more often exposed to air pollution, dust, cold air, and dryness which can cause changes in the mucosa and damage to the cilia so that the mucus in the sinuses cannot come out and becomes thicker with changes in $\mathrm{pH}$ so that it becomes a fertile medium for growth of germs or bacteria. Therefore chronic rhinosinusitis occurs (Dewi et al, 2012).

The clinical symptom most often complained of by chronic maxillary sinusitis patients was a cold as many as 45 patients (53.6\%). Research conducted by Shabrina et al (2017) at ENT Poli RSUD Dr. Soetomo Surabaya stated that the most frequent clinical symptoms of chronic rhinosinusitis were colds, as many as 70 patients (73.7\%) (Shabrina et al., 2017). Rhinorrhea is one of the symptoms of chronic rhinosinusitis. Based on the theory, colds can occur as a result of stimulation from exposure to irritants, therefore the nasal epithelium is replaced with goblet cells, causing mucus hypersecretion and decreased mucociliary activity (mucociliary activity). As a result of a decrease in mucociliary activity (mucociliary activity), it is one of the factors for chronic rhinosinusitis (Irawati and Rusmono, 2017). Nasal congestion occurs due to an inflammatory process, when the organs that form osteo-meatal complex and the inferior turbinate become infected, edema occurs, so that the opposite mucosa meets each other and the nasal cavity narrows. Cilia cannot move and cause the ostium to become clogged causing the mucus in the sinuses to not come out and become thicker with changes in $\mathrm{pH}$ so that it becomes a fertile medium for the growth of germs or bacteria and chronic rhinosinusitis occurs (Gultom, 2014).

The frequency of nasal septal deviation in patients with chronic maxillary sinusitis in this study was 35 patients (41.7\%) with nasal septal deviation and 49 patients $(58.3 \%)$ with no nasal septal deviation. The results of this study were similar to those conducted by Trihastuti et al (2015) at the ENT Poli RSUP Dr. M. Djamil Padang stated that 26 patients (41.27\%) had nasal septal deviation (Trihastuti et al, 2015). In chronic maxillary sinusitis patients, the frequency with nasal septal deviation is less than those without nasal septal deviation because the location of the deviation for each patient varies and does not always cover the maxillary sinus ostium or sinus paranasales (Dogan et al., 2016).

Other causes most commonly found in chronic maxillary sinusitis patients apart from nasal septal deviation were dental caries in 25 patients (29.8\%). Septiwati et al. (2013) conducted a study 
at the ENT clinic at Raden Mattaher Hospital, Jambi, to get the most causes besides septal deviation, dental caries as many as 22 patients (64.7\%) (Septiwati et al, 2013). Based on the anatomy, the maxillary teeth (except the incisors) were very close to the floor of the sinuses, especially the maxillary sinuses. the roots of 1 st and 2 nd molars and 2 nd premolars are covered only by mucous membrane and sometimes even protrude into the maxillary sinus. The base of the maxillary sinus is the alveolar process, which is where the roots of the maxillary teeth are located, so that the cavity of the maxillary sinus is only separated by a thin bone with the root of the tooth, sometimes even without a limiting bone. This short distance is very easy for dental infections to enter the maxillary sinus because it occurs chronic maxillary sinusitis. Dental infections or maxillary dental caries such as apical infections of the tooth roots or inflammation of the periodontal tissues easily spread directly to the sinuses or through blood or lymph vessels (Kusuma, 2014).

\section{CONCLUSIONS}

The conclusions that can be drawn based on the study results are the profile of chronic maxillary sinusitis sufferers is most common at the age of 46-55 years, more common in women, and the most frequent clinical symptom is rhinorrhea. The frequency of nasal septal deviation in patients with chronic maxillary sinusitis was 35 patients with nasal septal deviation and 49 patients with no nasal septal deviation. Other causes besides nasal septal deviation in chronic maxillary sinusitis patients the most are dental caries. It is necessary to study with different predisposing factors besides nasal septal deviation to chronic maxillary sinusitis. It is necessary to organize and store the status of medical records neatly in the medical record room of General Hospital of Haji Surabaya.

\section{REFERENCE}

Arivalagan P, Rambe A, 2013,Gambaran Rinosinusitis Kronis di RSUP Haji Adam Malik pada Tabun 2011, Jurnal FK USU, 1, pp. 2 [online], (Diunduh pada tanggal 15 September 2017), Tersedia dari:https://jurnal.usu.ac.id/index.php/ ejurnalfk/article/view/1342.

Aziz T, Biron VL, Ansari K dkk, 2014, Measurement Tools for The Diagnosis of Nasal Septal Deviation, Journal of Otolaryngology - Head and Neck Surgery, 43, pp. 1-9 [online], (Diunduh pada tanggal 10 September 2017), Tersedia dari : https://journalotohns.biomedcentral.com/articles/10.1186/1916-0216-4 3-11 .

DOI : 1001186/1916-0216-4 3-11. 


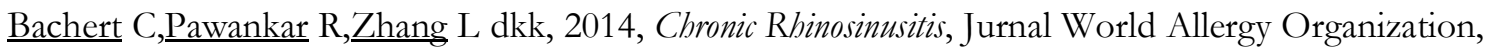
7, pp. 25 [online], (Diunduh pada tanggal 20 Juli 2018), Tersedia dari: https://www.ncbi.nlm.nih.gov/pmc/articles/PMC4213581/.

Chow AW, Benninger MS, Brook I dkk, 2012, IDS A Clinical Practice Guideline for Acute Bacterial Rhinosinusitis in Children and Adults, Oxford Journals, 54, pp. 84-86 [online], (Diunduh pada tanggal 4 September 2017), Tersedia dari: https://academic.oup.com/cid/article/54/8/e72/367144.

Dewi E, Hasibuan M, Nursiah S dkk, 2012, Profil Penderita Rinosinusitis Kronik Yang Menjalani Bedah Sinus Endoskopik Fungsional Di Rumah Sakit H. Adam Malik Medan 2008-2011, 45, pp. 136139.

Dogan R, Tugrul S, Erdogan EB dkk, 2016, Evaluation Of Nasal Mucociliary Transport Rate According To Nasal Septum, International Forum of Allergy \& Rhinology, 00, pp. 768-773 [online], (Diunduh pada tanggal 20 Agustus 2018), Tersedia dari: https://www.ncbi.nlm.nih.gov/pubmed/26854268.

Dykewicz MS, Hamilos DL, 2010, Rhinitis and Sinusitis, American Academy of Allergy, Asthma and Immunology, 125, pp. 110 [online], (Diunduh pada tanggal 22 September 2017), Tersedia dari:https://www.jacionline.org/arti cle/S0091-6749(09)02881-4/fulltext.

Ference EH, Tan BK, Hulse KE dkk, 2015, Commentary On Gender Differences In Prevalence, Treatment, And Quality Of Life Of Patients With Chronic Rhinosinusitis, Allergy Rhinol, 6, pp. 82-88 [online], (Diunduh pada tanggal 23 Juli 2018), Tersedia dari:https://www.ncbi.nlm.nih.gov/pubmed/263027 27.

Fokkens WJ, Lund VJ, Mullol J, dkk, 2012, European Position Paper on Rhinosinusitis and Nasal Polyps, Rhinology, 50, pp. 55 [online], (Diunduh pada tanggal 1 September 2017), Tersedia dari:http://ep3os.org/EPOS2012. pdf.

Fokkens WJ, Lund VJ, Mullol J, dkk, 2007, European Position Paper on Rhinosinusitis and Nasal Polyps, Rhinology, 45, pp. 1-139 [online], (Diunduh pada tanggal 1 September 2017), Tersedia dari:https://www.ncbi.nlm.nih.gov/pubmed/17844873.

Gultom JM, 2014, Gambaran Karakteristik Penderita Rinosinusitis di RSUD. Dr. Pirngadi Medan Pada Tahun 2012, Universitas HKBP Nommensen, Medan.

Harar R, Chadha NK, Rogers G, 2004, The Role of Septal Deviation in Adult Chronic Rhinosinusitis, Rhinology, 42, pp. 126-130 [online], (Diunduh pada tanggal 1 Oktober 2017), Tersedia dari:http://europepmc.org/abstract/med /15521664.

Husni T, Pradista A, 2012, Faktor Predisposisi Terjadinya Rinosinusitis Kronik di Poliklinik THT-KL RSUD Dr. Zainoel Abidin Banda Aceh, Jurnal Kedokteran Syiah Kuala, 12, pp. 132 [online], (Diunduh pada tanggal 3 Oktober 2017), Tersedia dari: http://www.jurnal.unsyiah.ac.id/JKS/article/view/3511.

Jackman AH, Kennedy DW, 2006, Pathophysiology of Sinusitis, In : Brook Itzhak, Sinusitis From Microbiology to Management, New York, pp. 109-129. 
Kaygusuz A, Haksever M, Akduman D dkk, 2013, Sinonasal Anatomical Variations: Their Relationship With Chronic Rhinosinusitis And Effect On The Severity Of Disease- A Computerized Tomography Assisted Anatomical And Clinical Study, Indian J Otolaryngol Head Neck Surg, pp. 1-7 [online], (Diunduhpada tanggal 1 Agustus 2018),Tersedia dari: https://www.ncbi .nlm .nih.gov/pmc/articles/PMC4071417/.

Levine HL, 2005, Diagnosis and Management of Rhinosinusitis, In : Levine HL, Clemente MP, Sinus Surgery Endoscopic and Microscopic Approaches, New York, pp. 90-99.

Mahdavinia M, 2013, Chronic Rhinosinusitis And Age: Is The Pathogenesis Different?, Expert Review Of Anti-infective Therapy, 11, pp. 1029-1040 [online],(Diunduh pada tanggal 18 Juli 2018), Tersedia dari: https://www .ncbi.nlm.nih.gov/pubmed/24073878.

Mundra RK, Gupta Y, Sinha R dkk, 2014, CT Scan Study of Influence of Septal Angle Deviation on Lateral Nasal Wall in Patients of Chronic Rbinosinusitis, Indian J Otolaryngol, 66, pp. 187-190 [online], (Diunduh pada tanggal 12 Oktober 2017), Tersedia dari:https://link.springer.com/article/10.1007/s120 70-014-0713-7. DOI: 10.1007/s120 70-014-0713-7.

Nagel P, Gurkov R, 2014, Sinusitis, In : Suwono WJ, Suyono YJ, Dasar-Dasar Ilmu THT, 2nd edn, Penerbit Buku Kedokteran EGC, Jakarta, pp. 42-43.

Peric A, Gacesa D, 2008, Etiology and Pathogenesis of Chronic Rhinosinusitis, Vojnosanitetski Pregled, 65, pp. 688-702 [online], (Diunduh pada tanggal 26 September 2017), Tersedia dari: http://scindeks-clanci.ceon.rs/data/pdf/0042-8450/2008/0042-84500809699P.pdf.

Rahmi AD, Punagi AQ, 2008, Pola Penyakit Subbagian Rinologi di RS Pendidikan Makassar periode 20032007, Bagian Ilmu Kesehatan THT FK Universitas Hasanuddin, Makassar.

Ramanan RV, Khan AN, Branstetter BF dkk, 2012, Sinusitis[online], (Diunduh pada tanggal 30 Oktober 2017), Tersedia dari:http://www.emedicine.com/RADIO/topic638.htm.

Salsabila H, 2017, Studi Epidemiologi Rhinosinusitis Kronis (RSK) Di Poli THT RSUP Dr. Sardjito Yogyakarta, Universitas Gadjah Mada, Yogyakarta.

Sambuda A, 2008, Korelasi Antara Rbinitis dan Sinusitis Pada Pemeriksaan Sinus Paranasalis Di Instalasi Radiologi RSUD Dr. Moewardi Surakarta, Universitas Sebelas Maret, Surakarta.

Scibberas NC, Xuereb HKB, 2008, Review of The Financial and Medicolegal Implications of Nasal Fracture Seen at St Luke's Hospital, Malta Medical Journal, 20, pp. $32-35$ [online], (Diunduh pada tanggal 28 September 2017), Tersedia dari: http://www.um.edu.mt/umms/mmj/PDF/218.pdf.

Septiwati M, Taher A, Rahayu U, 2013, Hubungan Infelesi Gigi Rahang Atas Dengan Kejadian Rhinosinusitis Maksilaris Di Rumah Sakit Umum Daerah Raden Mattaher Jambi, Universitas Jambi, Jambi.

Seyhan A, Ozaslan U, Azden S, 2008, Three-dimensional Modeling of Nasal Septal Deviation, Annals of Plastic Surgery, 60, pp. 157-161 [online], (Diunduh pada tanggal 5 Oktober 2017), Tersedia dari https://journals.lww.com/ 
annalsplasticsurgery/Abstract/2008/02000/Three_Dimensional_Modeling_of_Nasal_Se ptal.10.aspx.

Shabrina AF, Perdana RF, Atika, 2017, Gambaran Dan Faktor Risiko Penderita Rinosinusitis Kronik Di URJ THT-KL RSUD Dr. Soetomo Surabaya, Universitas Airlangga, Surabaya.

Soetjipto D, Dharmabakti US, Mangunkusumo E, 2006, Functional endoscopic sinus surgery di Indonesia pada panel abli THT Indonesia, Yanmedic-Depkes, Jakarta.

Soetjipto D, Mangunkusumo E, 2007, Sinusitis, In : Soepardi E, Iskandar N, Buku Ajar Ilmu Penyakit Telinga Hidung Tenggorok Kepala \& Leher, 6th edn, Balai Penerbit FKUI, Jakarta, pp. 150-153.

Soetjipto D, Mangunkusumo E, 2012, Rinorea, Infeksi Hidung dan Sinus, In : Soepardi E, Iskandar N, Bashirudin J, Restuti R, Buku Ajar Ilmu Penyakit Telinga Hidung Tenggorok Kepala \& Leher, 7th edn, Balai Penerbit FKUI, Jakarta, pp. 122-128.

Suhandoko LP, 2017, Hubungan Antara Deviasi Septum Nasi Dengan Rinosinusitis, Universitas Airlangga, Surabaya.

Tamus AY, Boesoirie MTS, Aroeman NA, 2015, Korelasi Antara Visual Analogue Scale (VAS) dan Peak Nasal Inspiratory Flow (PNIF) Sebelum dan Sesudah Septoplasti, MKB, 47, pp. 186-190 [online], (Diunduh pada tanggal 14 Oktober 2017), Tersedia dari:http://journal.fk.unpad.ac.id/index.php/mkb/ar ticle/view/601.

Timperley D, Schlosser RJ, Harvey RJ, 2010, Chronic Rhinosinusitis: An Education And Treatment Model, Otolaryngology-Head and Neck Surgery, 143, pp. 3-8.

Toluhula TT, Punagi AQ, Perkasa MF, 2013, Hubungan Tipe Deviasi Septum Nasi Klasifikasi Mladina dengan Kejadian Rinosinusitis dan Fungsi Tuba Eustachius, ORLI, 43, pp. 121 [online], (Diunduh pada tanggal 16 Oktober 2017), Tersedia dari: http://www.orli.or.id/index.php/orli/article/view/69.

Trihastuti H, Budiman BJ, Edison, 2015, Profil Pasien Rinosinusitis Kronik di Poliklinik THT-KL RSUP Dr. M. Djamil Padang, Jurnal FK Unand, 4, pp. 877-882 [online], (Diunduh pada tanggal 23 Juli 2018), Tersedia dari: http://jurnal.fk.unand.ac.id/index.php/jka/article/view/380.

Wee JH, Kim DW, Lee JE dkk, 2012, Classification and Prevalence of Nasal Septal Deformity in Koreans according to Two Classification Systems, Acta Oto-Laryngologica, 132, pp. 52-57 [online], (Diunduh pada tanggal 26 Januari 2018), Tersedia dari : http://www.tandfonline.com/doi/abs/10.3109/000164 89.2012.661077. $\quad$ DOI : $10.3109 / 000164$. 